Short Story

Canadian Journal of Family and Youth, 8(1), 2016, pp 243-248

ISSN 1718-9748 @ University of Alberta

http://ejournals.library.ualberta.ca/index/php/cjfy

\title{
Track and Field Day
}

Terry Trowbridge

\begin{abstract}
This personal essay reflects on adolescent experiences of sport. The author points out how middle school is a time when he began develop critical consciousness, by thinking about the political power of space, place, time, and social hierarchies, through his experiences of Track and Field Day and Boy Scout camp.
\end{abstract}

Terry Trowbridge is now a PhD student in Socio-Legal Studies at York University. Correspondence concerning this article should be addressed to Terry Trowbridge, Graduate program in Socio-Legal Studies, York University, 4700 Keele St., Toronto, Ontario, M3J 1P3. Contact: trowbridgeterry@gmail.com. 
Short Story

Competitions usually have only one winner. I cannot recall when, exactly, but at some point in my adolescence I developed a sort of ambivalent interpretation of rankings of first, second, third place, or any placing in a competition. Foot races in our grade school Track and Field Day were my first experience of this ambivalence. Ranking ceased to be merely hierarchical to me but instead had multiple divergent, but interdependent, meanings. Here are five of them, all of which I experience to this day, in some analogous form, every time I witness or participate in any formal competition. But I will describe races because that is where my perceptions began to flake out.

First: tradition. By participating in Track and Field Day, I was participating in competitions that had existed in one form or another for centuries. I was connected to something through history. I still don't know what this satisfied feeling is called, even though I have a History degree. Conservatism, maybe.

Second: just desserts. First place was a winner because they deserved to win and every place afterward was a measurement of how the racers compared to each other at that moment and even, hypothetically, ever. As if that was the race, the race, and it was a quantitative measurement, from now until eternity, of all grade six boys. It wouldn't matter how much money they made after college, or which man was the better speller, or anything else. If I came in third place, I would be third place forever. I came in third place in the hundred meter dash in grade 5. In grade six I came in first. I even placed in the top five of high jump. I felt really good about myself and about the rankings. There was no reason to measure how tall I was against the other boys at my school ever again. Tallness was merely biological, and changed over time. How high we could jump was the Platonic ideal revealed. 
Short Story

Third: staring into infinity. Once a year, my middle school would suspend normal classes for a day and instead have Track and Field Day. Winners of the track events would go on to a regional competition between other middle schools. Winners of those competitions would compete at the provincial level. Then, winners of those competitions would compete in national Track and Field meets. But for everyone who did not win an event, there was no way of knowing why they participated. Some students even wandered off or skipped events they were signed up to do. Some students stayed home. Students who were competing in order to win would almost always lose and therefore had to reevaluate the purpose of their day. The geography of it all, the movement of students from home, to local region, to province, to a nation, was almost utterly abstracted to the point of meaninglessness and only made sense in the strange and inhuman purpose of the school itself, and did not make sense to any of the humans who lived in the school. In other words, there were infinite meanings that could be experienced in every rank in every event. If I wanted to know what it meant to place first, second, or third, I was confronted with finite, or maybe transfinite, chaos. This infinity of emotions was what I thought I was witnessing and what I felt I was empathizing with when I looked at the children scattered over the fields at lunchtime. I was interested in the meaning of the word "transfinite" in Grade 8 and maybe this explains my multiple perceptions somewhat.

Fourth: defeatism. For every race there was one winner and seven losers. Every winner would progress to the next level, which would allow one winner to remain a winner and make seven winners into seven more new losers. Every race was a loser machine. On further reflection, every team sport had a ratio of one winner to one loser. Leagues worked much the same as races. That is how I decided that sports are loser machines, designed to propagate losers at a tremendous rate. In the space of 100 meters and less than 30 seconds, seven losers could be 
Short Story

produced with only one winner, which was a remarkably small inefficiency. That inefficiency was easily corrected by making winners race each other.

I want to clarify that I never felt like defeatism had much to do with me, though. Defeatism was only real to the record keepers, like teachers and my peers who cared about sports. I thought (and still think), that keepers of sports statistics were especially vicious, but this defeat was only real to them. The emotion that now accompanies my perception of defeatism is pity and a righteous indignity toward people who talk about winners, as if winning has anything to do with the purpose of organized sports.

In their theory, the last winner of all is called a champion, and in their theory finding or creating a champion is the purpose of ranked competitions. Yet the purpose of the champion has very little to do with the person who wins, and instead serves a very important industrial function. If sports are machines that produce losers, then winners are inefficiencies. The champion is the way that the machine can take any number of people, no matter how many, and reduce its inefficiency down to merely 1 . In the final championship race, the champion is industrial genius personified. Logically, the very thing that plagues machines of all kinds is inefficiency. But in competitive sports, the inefficient dregs actually become the means by which the machine achieves its logical ratio of infinite potential efficiency to 1 . By adding annual cycles to a schedule of sports, champions even have a limited shelf life, ensuring that the inefficiency is contained to the smallest possible time before the machine can be reactivated. There is no such thing as a winner per se. The champion is merely a cog in a machine and somebody has to be that cog. However there is a deep and abiding contradiction in the anonymity of winning - that somebody, anybody has to win - which is also liberating. In fact, I 


\section{Short Story}

think winning contradicts all of my first three perceptions with a kind of sublime ontological equilibrium.

Fifth: any number of competitors wins every race. To my knowledge at the time, and to my knowledge still, there is no complete explanation of why any particular person actually wins any particular race. There are so many variables involved that all we can experience is who won a race, and which race was run, and any details that we want about the race. However, even when we can explain how the winner won the race, there is no way to prove that the winner had to win that particular race. The ranking of competitors told me only two certain things. The ranking of first, second, third, etcetera, told me who could have won the race: anyone on the list. The ranking was also a description that could be interpreted in any subjective way we would like. By grade 7 I had learned the word "kinesiology" and thought that the movement of bodies was beautiful. Therefore the ranking was in a very vague way implying a moment of beautiful movement which our bodies experienced, and most importantly, the ordinal numbers attached to how we all finished our movements were evidence that there were innumerable movements of which we were all capable. Any of the racers could finish in any of the possible places. In fact, any of the racers could even sprain an ankle and not finish the race, or even skip the race altogether. Many did.

But what did Track and Field Day mean? Appealing to tradition would seem, to the twisted belittling view of a statistic-keeper, to mean keeping track of winners and losers. But to me the race itself, with the promise of more races to follow, negated all agency from winning and losing. Losing was inevitable. Winning was satisfying but mostly satisfying if I thought about myself outside of the context of the race. All that the record showed was a crude way of recording complex and beautiful motions of our bodies, and those motions were complex and 
Short Story

beautiful enough to be appreciated independently of the slippery slope of elimination-style tournaments. Therefore ordinal rankings did not mean "first place compared to second, second place compared to third, etcetera..." Rankings were more like pictures of what happened and an acknowledgement of what could have been, and both what was and what could be were facilitated by the same beautiful movements.

I know also that this final interpretation was ingrained in me by seventh grade because of something that happened at Boy Scout camp. My patrol had won several competitions at a very large Scout camp, placed second and third in a few others. These events were slightly more complicated than Track and Field Day. One event was a race to see which Scout troop could saw through a large log the fastest, which had a certain danger with a two-person saw and some lumberjack philosophy at stake. Another race measured our preparedness for crisis by assigning one Scout to feign a broken leg while the troop performed first aid, built a stretcher in the forest, and then carried him dozens of meters over rough terrain. Not all events were heroically existential. We even placed in a purely cerebral race against other troops, which was knot tying.

We had amassed our trophies and our troop's Scouters were taking our photograph, when one of them told us to get the second and third place trophies out of the picture. He said that they were "an insult." He explained that second and third place only show us how much we lost by, and that nobody wanted pictures of that. "We do," I said. And we kept the trophies in, despite the Scouters' disdain. 